\title{
SECURITY OF SUPPLY AND TENURE ${ }^{1}$ BY OEORGE B. AMIDON2
}

A great many changes have taken place in the woods in both the United States and Canada during the past ten years. One of the most significant changes has been the impressive progress made in forest management. It seems doubtful that any other period in our history has made as significant a contribution to the development of a sound conservation program.

To those living close to the forests and concerned with everyday problems of management, progress may seem slow and sometimes discouraging. But if we focus our attention on the forest, look back ten years or so and compare the situation then with now, we must, I believe, conclude that the job of growing wood has taken on real meaning in this short span of time.

This progress is most evident, I believe, in industrial forestry. Spurred by the increased demand for forest products of all kinds, the timber industry has enjoyed great development. Along with this development has come a greater appreciation of the science of forest management. Application of forest management principles and practices by industry, individual companies and by tree farmers, is evidenced by the healthy growth of the tree farm program in the United States which started in 1940 with a single operation of 121 , 000 acres and has now expanded to 29 states and taken in more than $22 \mathrm{mil}$ lion acres. Along with this program has gone a corresponding improvement in cutting practices on large areas of private forest land. Further evidence of this is the number of industrial foresters employed in the U.S. which has increased from just over 1,000 in 1940 to 3,100 in 1950 . I do not have similar figures for Canada, but I believe that the increase here in the employment of foresters by industry is equally, if not more, impressive.

Past progress, impressive as it may be, is not, however, of lasting satisfaction if problems remain unsolved. In the field of forest management there is no shortage of problems and the opportunities for greater progress in the future seem better than ever.

This is so because of the tremendous increase within recent years in the use and value of wood and the growing recognition of its important contribution to our standard of living. Evidence of this is the fact that the pulp and paper industry used 10 million cords more pulpwood in the United States and 4 million cords more in Canada in 1952 compared to 1945. Paper consumption per capita has increased from 254 pounds in 1940 to about 400 pounds in 1952 in the United States and in Canada from about 130 pounds in 1940 to approximately 260 pounds in 1952.

This increase in the use of pulpwood has averaged two million cords annually for the two countries during the past seven years. This will likely taper off in the future but if current per capita consumption is just maintained, the normal increase in population alone will require nearly three-quarters of a million cords of pulpwood annually.

These figures all point to the need for more intensive forestry. They indicate that wood will be of greater value in the future, that this part of the

? A Paper prepared for the 1953 Annual Meeting of C.I.F. at Winnipeg.

2 Minnesota and Ontario Paper Company. 
world is approaching the time when intensive forest management will be the most economic way of handling the forests and that perhaps a review of old conceptions of forest land ownership and management is now necessary if we are to keep pace with changes which have taken place in the use of this raw material.

It is my contention that the problem of land tenure and security of supply are matters of considerable importance in determining the extent and rate of progress in improved forest management in both the United States and Canada. This is discussed briefly in the following paragraphs under two headings, (1) The Advantages of Private Ownership and (2) What is a Desirable Ownership Distribution of Forest Lands?

\section{The Advantages of Pruvate OWnership}

In the preceeding introductory statement, I have attempted to say that in spite of the impressive progress made in forest management in the past ten years the opportunities for improved forestry are greater in the future because of the increasing use and value of wood. I have also tried to indicate that if too large a percentage of forest land is held in any one type of ownership, progress will not be as rapid as it would be if there were a more equal distribution of forest land.

To be more specific, it seems to me that in some parts of the United States and Canada, the large percentage of forest land in public ownership is retarding progress in forest management. This does not mean that $I$ do not recognize the excellent job that is being done on many of the public forests nor does it mean that I am opposed to public ownership of forest land. I also appreciate that there are good reasons why there is so much land in public ownership in certain areas and believe that any transfer of public lands to private ownership must provide for safeguards that will protect the public interest.

Many private owners have given clear evidence that they are in the timber growing business to stay and are managing their lands in accordance with sound forestry principles. Large sums of money are being spent by industry on their forestry programs, and in many cases the number of acres of company owned forest land for each forester employed is much smaller than on most public forests. This does not necessarily mean that these industrial forests are being managed better than public forests but other things being equal, the more foresters for a given area, the better the management. If this is so, then the more land which this type of owner is willing to manage, the better the overall forestry job. Therefore, the transfer of certain public lands to such owners would seem to be in the public interest.

There is nearly a billion acres of productive forest land in Canada and the United States and it seems safe to say that this land is presently growing less than one-half as much wood as it is capable of growing with more intensive management. It will undoubtedly be many years before this tremendous acreage reaches its peak in growth regardless of who owns the land because of the economic factors involved and the magnitude of the management job. However, it seems evident that the way to make progress most rapidly 
toward the goal of better forest management and maximum yield is to let everyone who is willing and able, help with the job.

Most public agencies of my acquaintance have more land than they can properly manage with the money available for management. This situation is improving but there is still a long way to go. Many areas are still so inaccessible that large volumes of timber are going to waste, due in part to the lack of access roads. Fire protection is still far from adequate in some areas and protection against insects and disease is hardly beyond the stage of classroom discussion. Large areas of public lands are in need of planting and at present rates of accomplishments, the size of the job is increasing every year. Some public forests are not even operating under a forest management plan.

This does not imply criticism of the public agencies, but merely indicates the difficulties of selling the taxpayer on the large expenditures required to properly manage the public forests. Neither does it imply that if this land were in private ownership, all these problems would automatically be solved. However, it does indicate that the job is too big for any one agency and all willing hands should be encouraged to help get the job done.

It seems evident that forest industries permanently established and farmers or other individuals who have land dedicated to the growing of timber crops will do a better job of managing their own forest land than they can be made to do on someone elses land, regardless of the quality of supervision. Therefore, by encouraging private ownership of forest land, the burden of the public agencies is lessened, more people become directly concerned with the problem and the job of growing the maximum wood on as many acres as possible seems more easily solved.

Besides growing more wood by means of getting more people to grow wood, there is another very important aspect of this problem. It is believed that ownership of a supply of raw material encourages the establishment and expansion of an industry dependent upon such raw material. For example, if a pulp and paper company has an assured continuous supply of wood there is much greater incentive to invest in the needed manufacturing facilities to use all of the wood available on its timbered area. This is also true of smaller wood using industries. Better planning is possible under such conditions and, consequently, the economic climate is much better than it would be if no assured supply of wood were available.

If this analysis seems logical, it follows then that forest lands under responsible private ownership is highly desirable and that too large a percentage in public ownership may actually retard maximum use and good management of the forest resources.

\section{What is a Desirable Ownership Distribution of Forest Lands}

This is a difficult question to answer because it depends on a number of different factors. It varies with the type of industry. Management of a pulp mill costing 20 to 40 million dollars would look upon this problem differently than a sawmill operator with an investment of $\$ 50,000$. The policy of the 
government or other owners of forest land in regards to timber sales, as well as the extent of development of the area, quality of soil, recreational and watershed values, and type of timber would all have a bearing on this question. However, it we take a specific case, it may help to shed some light on this problem.

In Minnesota there are nearly 17 million acres of productive forest land. About 11 million acres or nearly 60 percent of the total is in public ownership divided as follows: 4 million acres in county ownership, 4 million acres owned by the State and 3 million acres in Federal ownership. The major industries in Minnesota own less than 500,000 acres.

The pulp and paper industry has indicated that it would like to own enough land to eventually supply about one-third of its needs. To do this the mills would need about 400,000 acres more land than they now own or less than 4 percent of the land presently in public ownership.

The pulp and paper producers in Minnesota believe they are doing a good job of forest management. They are spending more money per acre in managing their own lands than any of the public agencies, they are planting more trees and eventually expect to be growing more wood. If they grow only one-third of their needs, there is certainly no danger of their having a monopoly of the timber supply. Therefore, it would appear to be in the public interest if the public agencies sold this amount of land to this industry.

About the only forest lands available to industry in Minnesota are those lands in public ownership so most of this 400,000 acres would have to come from this source. In addition, there are individuals who are interested in buying forest land and about their only source would also be the public lands.

If such sales were made under proper safeguards to assure that the lands were managed for continuous timber crops, it is doubtful that it would total over 500,000 acres to both industrial and small owners. This would still leave over 50 percent of Minnesota's forests in public ownership.

As noted above, the desirable distribution varies in different areas. However, it is significant to note that Sweden, which is considered to have some of the best managed forests in the world, only has 24 percent of its land in public forests. In the United States, 25 per cent of the productive forests are in public ownership, but this varies from 1 percent in the State of Maine to nearly 90 percent in the States of Wyoming and Utah. In Canada, 86 percent of all productive forest land is owned by the public.

From this it would appear that there is need for more lands in private ownership in some states in the United States and in many parts of Canada.

In conclusion, I would like to suggest that this distinguished audience give serious thought to the possible advantages, to the impetus to the overall forestry job, that could result, if more of Canada's forests were in responsible private ownership. This would, I believe, result in more and better use of Canada's forests and would mean a more secure supply for the industry, which last year provided more than 225 million dollars in wages and salaries to about 58,000 Canadian employees and their families. 